\title{
Neglected Infected Post-traumatic Pseudoaneurysms of Anterior Tibial Artery: A Case Report and the Lessons Learnt
}

\author{
Hari Venkatramani ${ }^{1}$ Madhu Periasamy ${ }^{1}$ Vamseedh \\ ${ }^{1}$ Division of Plastic Surgery, Hand Surgery, Reconstructive \\ Microsurgery and Burns, Ganga Hospital, Coimbatore, Tamil Nadu, \\ India \\ Indian J Plast Surg 2022;55:124-125.
}

\author{
Address for correspondence S. Raja Sabapathy, MS(Gen), MCh \\ (Plastic), DNB(Plastic), FRCS (Edin), FAMS, Hon FRCS(Glasgow), Hon \\ FACS, DSc(Hon), Division of Plastic Surgery, Hand Surgery, \\ Reconstructive Microsurgery and Burns, Ganga Hospital, 313 \\ Mettupalayam Road, Coimbatore, Tamil Nadu, 641043, India \\ (e-mail: rajahand@gmail.com).
}

Vascular injuries due to trivial trauma are rare and infrapopliteal vascular injuries in this subset of injuries are even less common in the absence of crush injuries and bony fractures.

A 52-year-old gentleman, an agriculture laborer, sustained an injury to his left leg when he accidentally banged against a wooden log. There was a wound in his distal left leg, which was sutured at a nearby hospital on the day of injury. The postoperative period was uneventful until he noticed bleeding from the wound on day 5 after injury, which was managed with pressure bandage and ligation of bleeders. He experienced repeated episodes of bleeding on the 42nd and 45th day post injury. He had undergone ligation of the bleeders repeatedly on outpatient basis at the same hospital before presenting to us with an ill-defined pulsatile swelling of $\sim 5 \times 6 \mathrm{~cm}$ in size beneath the $6 \mathrm{~cm}$ long infected sutured wound in the distal left leg (-Fig. 1). There was purulent discharge and the viability of the sutured skin was precarious. Arterial Doppler showed a pseudoaneurysm of the left anterior tibial artery with good distal flow in both the anterior and posterior tibial arteries. On exploration, a $4 \times 6 \mathrm{~cm}$ pseudoaneurysm of the anterior tibial artery was seen (-Fig. 2A). Pseudoaneurysm was excised and the anterior tibial artery was ligated proximally and distally after ascertaining distal vascularity. The infected skin was debrided and there was a defect of $6 \times 5 \mathrm{~cm}$ exposing the underlying tendons. Hence a peroneus brevis muscle flap resurfaced with skin graft was used to cover the defect
(-Fig. 2B). Postoperatively and at follow-up of 6 months, he was asymptomatic and the flap had settled well (-Fig. 3 ).

Infrapopliteal pseudoaneurysms are less common and the true incidences of such injuries leading to pseudoaneurysms are not exactly known. ${ }^{1}$ Anterior tibial artery pseudoaneurysms were reported in $43 \%$ of the cases. ${ }^{2}$ Most common symptoms at the time of diagnosis was swelling, pain, and bleeding. ${ }^{3}$ Herald bleed usually harbinger torrential threatening bleeds. ${ }^{4}$ When such herald bleeds occur, the history should be revisited and the vascular injury and sequel should be investigated. Neglected pseudoaneurysms that get infected leads to necrosis of the overlying skin and adds to the complexity of treatment. Debriding surgically the skin and soft tissue to healthy planes under good tourniquet control sooner addresses the infection. The pseudoaneurysm needs to be tackled either by reconstruction of vessels, which is risky in presence of infection, or ligating the ends of the vessel after ascertaining the distal vascularity. Endovascular procedure is also a possible option in these situations. Finally, the reconstruction of skin and soft tissue by local flaps is necessary. Muscle flaps do better in eradicating infection by filling cavities and thus reducing dead spaces. ${ }^{5}$ Free flaps must be used judiciously in the presence of infection and compromised vessels. High index of suspicion should be there among the professionals treating trauma conditions for early diagnosis and treatment. Infected pseudoaneurysms add complexity to the treatment. published online

February 25, 2022
DOI https://doi.org/ $10.1055 / \mathrm{s}-0041-1740525$ ISSN 0970-0358.

\footnotetext{
(C) 2022. Association of Plastic Surgeons of India. All rights reserved. This is an open access article published by Thieme under the terms of the Creative Commons Attribution-NonDerivative-NonCommercial-License, permitting copying and reproduction so long as the original work is given appropriate credit. Contents may not be used for commercial purposes, or adapted, remixed, transformed or built upon. (https://creativecommons.org/ licenses/by-nc-nd/4.0/)

Thieme Medical and Scientific Publishers Pvt. Ltd., A-12, 2nd Floor, Sector 2, Noida-201301 UP, India
} 


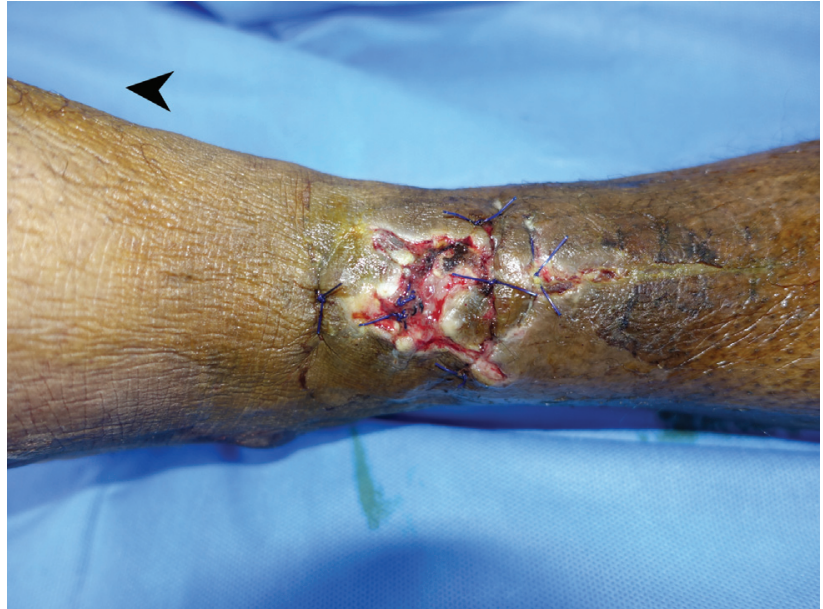

Fig. 1 Presenting clinical picture showing sutured wound with necrosis of surrounding skin in the distal leg (arrowhead pointing toward the foot).

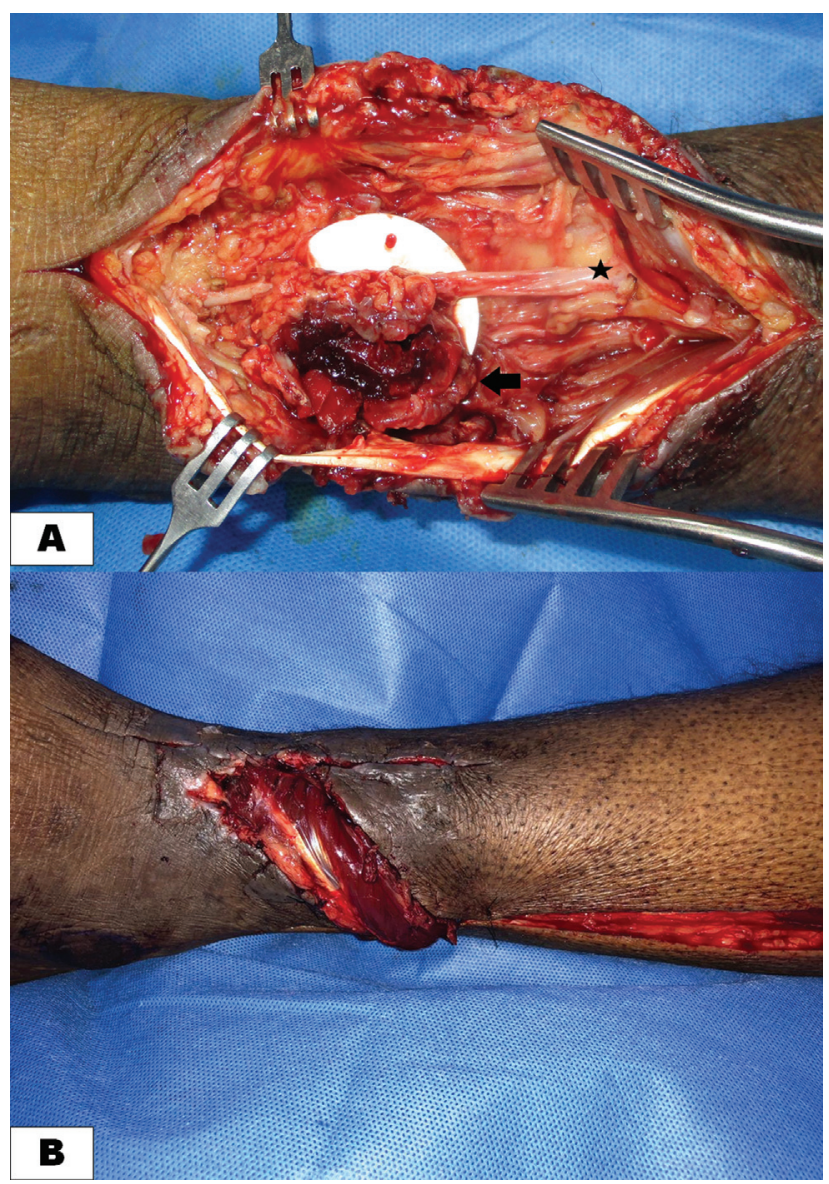

Fig. 2 (A) Intraoperative picture showing pseudoaneurysm (marked by arrow) of the anterior tibial artery (marked by star) dissected out from surrounding tissues. (B) Intraoperative picture after the excision of pseudoaneurysm with defect covered with peroneus brevis flap that was resurfaced with skin graft afterwards.

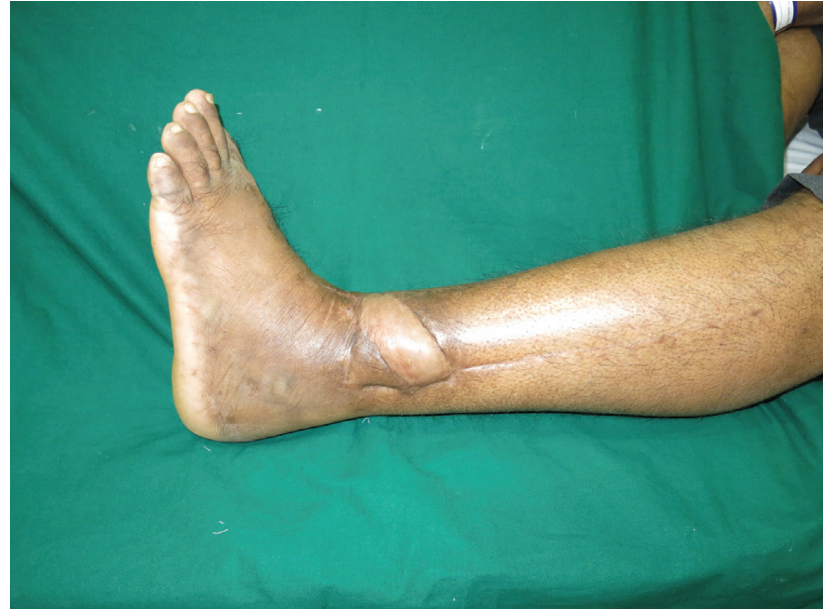

Fig. 3 Six-month follow-up picture showing the well settled muscle flap and skin graft.

\section{Funding}

This research did not receive any specific grant from funding agencies in the public, commercial, or not-forprofit sectors.

\section{Conflict of Interest \\ Nil}

\section{References}

1 Drapanas T, Hewitt RL, Weichert RF III, Smith AD. Civilian vascular injuries: a critical appraisal of three decades of management. Ann Surg 1970;172(03):351-360

2 Davis KA, Mansour MA, Kang SS, et al. Pseudoaneurysms of the extremity without fracture: treatment with percutaneous ultrasound-guided thrombin injection. J Trauma 2000;49(05): 818-821

3 McNutt R, Seabrook GR, Schmitt DD, Aprahamian C, Bandyk DF, Towne JB. Blunt tibial artery trauma: predicting the irretrievable extremity. J Trauma 1989;29(12):1624-1627

4 Zink JN, Netzley R, Erzurum V, Wright D. Complications of endovascular grafts in the treatment of pseudoaneurysms and stenoses in arteriovenous access. J Vasc Surg 2013;57(01): 144-148

5 Klebuc M, Menn Z. Muscle flaps and their role in limb salvage. Methodist DeBakey Cardiovasc J 2013;9(02):95-99 